\title{
Effects of freshwater flow on abundance of estuarine organisms: physical effects or trophic linkages?
}

\author{
W. J. Kimmerer* \\ Romberg Tiburon Center, San Francisco State University, 3152 Paradise Drive, Tiburon, California 94920, USA
}

\begin{abstract}
All ecosystems are influenced by physical forcing. Estuarine ecosystems respond most strongly on an interannual timescale to variability in freshwater flow. Several mechanisms for positive or negative flow effects on biological populations in estuaries have been proposed; however, positive effects appear to operate mainly through stimulation of primary production with effects propagating up the food web. In the northern San Francisco Estuary, abundance or survival of several common species of fish and shrimp varied positively with flow-in data through 1992. I re-examined these relationships and those of several additional taxa in an analysis of long-term (20 to $40 \mathrm{yr}$ ) monitoring data. The spread of the introduced clam Potamocorbula amurensis in 1987 provided an opportunity to examine simultaneously the responses of estuarine species to flow and to changes in the food web. I separated variability into a flow response, a step change after 1987 and other sources of variability. Responses of fish and shrimp contrasted with those of lower trophic levels. All but 1 species of nekton responded positively to flow, only 2 had clear declines after 1987, and none of the relationships changed in slope after 1987. In contrast with the higher trophic levels, chlorophyll $a$ (chl a) and several species of zooplankton declined markedly after 1987, and had either weak responses to flow or responses that changed after 1987. Thus, the food web appears strongly coupled between benthos and plankton, and weakly coupled between zooplankton and fish, as has been found in other systems. More importantly, the variation with freshwater flow of abundance or survival of organisms in higher trophic levels apparently did not occur through upward trophic transfer, since a similar relationship was lacking in most of the data on lower trophic levels. Rather, this variation may occur through attributes of physical habitat that vary with flow.
\end{abstract}

KEY WORDS: Estuary $\cdot$ Food web $\cdot$ Freshwater flow $\cdot$ Salinity $\cdot$ Introduced species

\section{INTRODUCTION}

Estuarine ecosystems provide goods and services with high economic value (Costanza et al. 1997) including significant fisheries (Houde \& Rutherford 1993). They are subject to substantial alteration by humans (Nichols et al. 1986) and they may play a significant role in the global carbon balance (Smith \& Hollibaugh 1993). Much of the high temporal and spatial variability in physical, chemical and biological con-

\footnotetext{
*Email: kimmerer@sfsu.edu
}

ditions in estuaries occurs through seasonal and interannual variability in freshwater flow (Skreslet 1986). River discharge into many estuaries is substantially altered by diversion for human use and may be sensitive to climate change (Vörösmarty et al. 2000). Thus, understanding mechanisms by which estuarine ecosystems respond to freshwater flow should yield important insights into the dynamics of these key ecosystems as well as their sensitivity to human intervention and climate variability.

Numerous examples exist in which estuarine populations or communities vary with freshwater flow. Pos- 
itive flow effects have been reported for phytoplankton production (Riley 1937, Cloern et al. 1983, Ingram et al. 1985, Malone et al. 1988, Gallegos et al. 1992, Mallin et al. 1993, Sin et al. 1999), and abundance or harvest of benthic invertebrates (Aleem 1972, Gammelsrød 1992, Montagna \& Kalke 1992, Wilber 1992, 1994) and fish (Stevens 1977, Houde \& Rutherford 1993, Jassby et al. 1995). Negative effects on biological populations can also occur, e.g. through effects of washout or osmotic stress (Deegan 1990, Kaartvedt \& Aksnes 1992), or combinations of effects (Howarth et al. 2000). Rose \& Summers (1992) found instances of positive, negative and no effects of freshwater flow on estuarine fish populations.

Estuarine populations may respond to increasing freshwater flow through several alternative mechanisms (Drinkwater \& Frank 1994). Increased nutrient loading may stimulate phytoplankton production (Riley 1937) according to the 'agricultural model' (Nixon et al. 1986), which may apply in many estuaries (e.g. De Jonge et al. 1994). Sutcliffe $(1972,1973)$ proposed that increased freshwater flow and nutrient loading stimulated phytoplankton production, increasing fishery yield. Sutcliffe's argument was disputed by Drinkwater \& Myers (1987) on statistical grounds and by Sinclair et al. (1986) on the basis of interpretation, but the concept has persisted. Phytoplankton blooms can also be stimulated through haline stratification, which may be correlated with freshwater flow (e.g. Cloern 1991).

To explain flow effects on animal populations, both the agricultural model and the stratification model require trophic transfer up the food web. Aquatic ecosystems including estuaries may show stronger food-web dynamics than terrestrial systems (Polis 1999). However, estuarine systems are also open and strongly influenced by physical variability, which may obscure food-web effects. Furthermore, the concept of 'bottom-up' regulation oversimplifies the responses of real aquatic food webs to stimulation at their base (e.g. McQueen et al. 1989, Micheli 1999).

Numerous environmental attributes may covary (positively or negatively) with freshwater flow and contribute to mechanisms for population responses to flow. Examples include: (1) flow patterns in the watershed and freshwater reach, such as flooding of river margins and proportion of freshwater diverted for human use; (2) changes in loading or dilution of materials from the watershed including nutrients, organic matter, sediments, contaminants and planktonic organisms; (3) physical changes in the estuary including the movement and compression of the estuarine salt field, stratification, residual circulation and residence time; and (4) changes in the hydrodynamic environment, such as the location and amplitude of maxima in turbidity, and chemical and biological constituents of the estuary (Postma 1967, Jassby et al. 1993, 1995, Monismith et al. 1996, 2002). Because this list is so long, statistical analyses may fail to distinguish among alternative mechanisms underlying any particular relationship with flow. Nevertheless, such analyses can be helpful in eliminating possible mechanisms.

In this paper, I examine long-term (20 to $40 \mathrm{yr}$ ) monitoring data from the San Francisco Estuary to determine modes of variability related to flow and those related to long-term changes in the food web. The San Francisco Estuary is a large, strongly tidal, heavily modified estuary with a residence time on the order of months (Walters et al. 1985). Most of the historic fringing marsh has been eliminated (Nichols et al. 1986) and most of the organic carbon supply to the open water is from phytoplankton (Jassby et al. 1993, Canuel et al. 1995, Jassby \& Cloern 2000). The emphasis in this paper is on the northern estuary (San Pablo Bay to the western Sacramento-San Joaquin Delta, Fig. 1), the region of greatest variability due to freshwater flow. A suite of estuarine-dependent pelagic species has been selected for analysis including all those discussed by Jassby et al. (1995). I have added several fish species, the abundant copepod Acartia spp. and rotifers, and chlorophyll a ( $\mathrm{chl} \mathrm{a)} \mathrm{concentra-}$ tion in 2 salinity ranges. The species included in the analysis are mostly abundant estuarine-dependent species present for the duration of the monitoring programs and have contrasting life history patterns, including several anadromous fish species and a number that spawn in the ocean or the lower estuary and move up the estuary as young (see Table 1).

Some relationships of population attributes to flow in the San Francisco Estuary have been reported before. Flow was once a good predictor of abundance of striped bass young-of-year (YOY) (Turner \& Chadwick 1972) and recruitment (Stevens 1977) indices, although declines in the spawning stock appear to have reduced that predictive capacity (Kimmerer et al. 2001). Abundance of the bay shrimp Crangon franciscorum (Hatfield 1985) and young of several fish species (Stevens \& Miller 1983) varied with freshwater flow. Jassby et al. (1995) presented relationships of abundance of a few estuarine-dependent species to a salinity variable called $\mathrm{X}_{2}$, which is the horizontal distance up the axis of the estuary to where tidally averaged near-bottom salinity is $2 \mathrm{psu}$, i.e. roughly the center of the low salinity zone (LSZ, defined as salinity of 0.5 to $6 \mathrm{psu}$ ). This variable reflects the physical response of the estuary to changes in flow and provides a geographic frame of reference for estuarine conditions. Salinity between 2 and about $30 \mathrm{psu}$ is roughly linearly distributed between $\mathrm{X}_{2}$ and the mouth of the estuary (Monismith et al. 1996). 
An inadvertent experiment provided a glimpse into the trophic processes in the estuarine pelagic food web. The introduced clam Potamocorbula amurensis spread throughout San Pablo and Suisun Bays and into the western Delta in 1987, reducing chl a along with abundance of larger phytoplankton and some zooplankton later that year and into subsequent years (Alpine \& Cloern 1992, Kimmerer \& Orsi 1996, Orsi \& Mecum 1996, Lehman 2000). Adding 7 to 8 yr of data after this event to those analyzed by Jassby et al. (1995) allowed for a contrast between food-web and flow effects. The flow responses reported by Jassby et al. (1995) could have arisen through stimulation at the base of the food web or through direct physical effects. If the responses to flow were due to food-web effects, we would expect 2 conditions to be true: (1) either positive or trophically alternating responses should be seen in the lower as well as higher trophic levels; and (2) changes in the flow responses due to the loss of phytoplankton biomass after 1987 should be similar at lower and higher trophic levels. I show here that the responses of lower and higher trophic levels were qualitatively different, implying that mechanisms for the responses of fish and shrimp to flow were not due to effects of flow on the base of the food web.

Jassby et al. (2002) detected 2 modes of variability in chl $a$ and primary production in the Delta (see Fig. 1). The first was a long-term decline in summer chl a concentrations, which they attributed to the grazing by Potamocorbula amurensis. The second was a winterspring mode that varied inversely with flow and had a long-term decline of unknown cause. Analyses presented here focus on spring-summer, when the fish and shrimp are in larval and juvenile stages, and on salinity above $0.5 \mathrm{psu}$. This implies some overlap with the data used by Jassby et al. (2002), although as shown below, the patterns of variability were somewhat different.

\section{METHODS}

Sources of data and the methods used to calculate $\mathrm{X}_{2}$ were explained in detail by Jassby et al. (1995) and are described only briefly here. Daily values of $\mathrm{X}_{2}$, the distance up the axis of the estuary to where daily average near-bottom salinity is $2 \mathrm{psu}$, were calculated from 1968 to 1992 by interpolation among fixed salinity monitoring stations. For other years, $\mathrm{X}_{2}$ was calculated from time series regression relating $X_{2}$ to the previous day's $X_{2}$ and the log of the current day's net freshwater flow into the estuary, which is calculated from gauged flows and estimated net consumption in the Delta (California Department of Water Resources unpubl. data). Values used were means over 1 or more months, so errors in freshwater flow estimates had at most a minor effect on the $\mathrm{X}_{2}$ values. Error variance for the estimation of daily $\mathrm{X}_{2}$ values was $\sim 2 \mathrm{~km}^{2}$ (Jassby et al. 1995). Variance of seasonally averaged $\mathrm{X}_{2}$ values was $\sim 100 \mathrm{~km}^{2}$; therefore, $\mathrm{X}_{2}$ can be treated as if measured without error. The averaging period for $\mathrm{X}_{2}$ differed among species: it was based generally on the larval development periods of the fish and shrimp (Jassby et al. 1995) or for planktonic species, the months during which samples were taken.

Data to develop biological response variables were obtained from the database of the Interagency Ecological Program for the San Francisco Estuary (IEP; www.iep.water.ca.gov), a consortium of state and federal agencies that runs several estuarine monitoring programs. Response variables included chl $a$, abundance of several planktonic taxa, and annual indices of abundance or survival of several species of fish and shrimp (Tables 1 \& 2). These monitoring programs have used consistent methods since their inception, although the number and distributions of stations have changed in some cases. All response variables were log-transformed to homogenize error variance, with constants added in some cases to account for 0 catches in the data.

Data for lower trophic levels were obtained from IEP monitoring programs that focus on Suisun Bay and the Delta, with at most 2 stations in San Pablo Bay (Fig. 1). Zooplankton abundance data were obtained from the IEP zooplankton monitoring program, in which samples have generally been taken monthly in March and

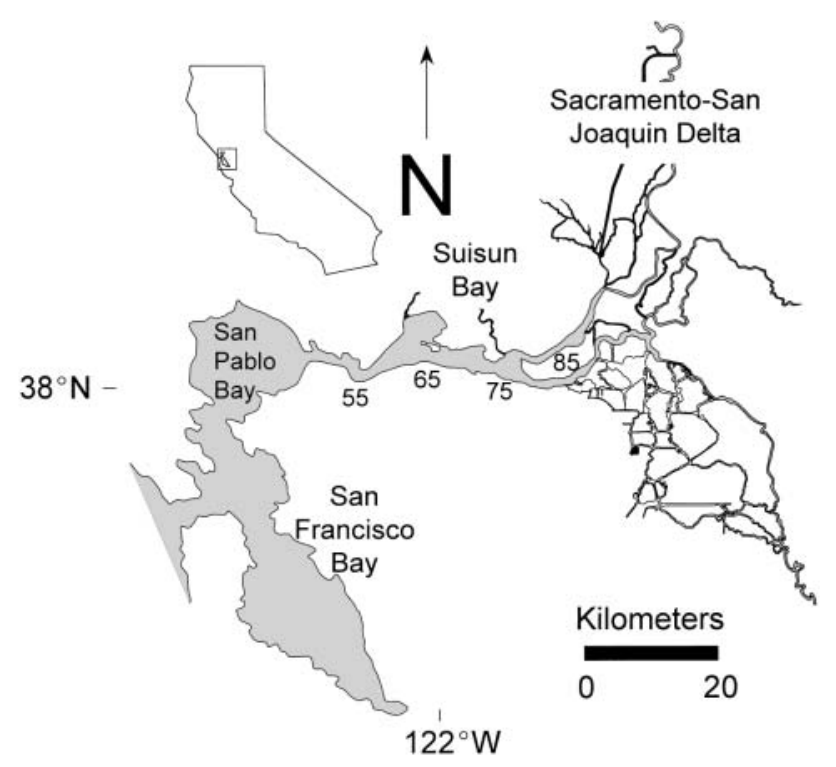

Fig. 1. San Francisco Estuary showing sub-embayments and the Sacramento-San Joaquin Delta. Numbers indicate distance up the axis from the mouth of the estuary $(\mathrm{km})$ 
Table 1. Summary of life history information for species discussed

\begin{tabular}{|c|c|c|}
\hline Taxon & Life history information & Source \\
\hline $\begin{array}{l}\text { Copepod } \\
\text { Eurytemora affinis }\end{array}$ & $\begin{array}{l}\text { Resident of the low salinity zone (LSZ), since } 1987 \text { abundant only in } \\
\text { spring. Common in low salinity regions of estuaries worldwide and an } \\
\text { invader of artificial freshwater bodies. Consumes phytoplankton, can live } \\
\text { on detritus. }\end{array}$ & $\begin{array}{l}\text { Heinle et al. (1977), } \\
\text { Kimmerer et al. (1998), } \\
\text { Lee (1999) }\end{array}$ \\
\hline $\begin{array}{l}\text { Copepod } \\
\text { Acartia spp. }\end{array}$ & $\begin{array}{l}\text { Mostly A. hudsonica (identification uncertain), some A. californiensis and } \\
\text { A. tonsa, species not distinguished in monitoring program. Common at } \\
\text { moderate to high salinity in estuaries worldwide. Consumes phytoplankton } \\
\text { and microzooplankton. }\end{array}$ & $\begin{array}{l}\text { Ambler et al. (1985), } \\
\text { Stoecker \& Egloff (1987), } \\
\text { Kimmerer \& Orsi (1996) }\end{array}$ \\
\hline $\begin{array}{l}\text { Rotifer } \\
\text { Synchaeta bicornis }\end{array}$ & $\begin{array}{l}\text { Resident of the LSZ of many estuaries. Small zooplankter, filter-feeder on } \\
\text { phytoplankton, detritus, microheterotrophs and bacteria. }\end{array}$ & Holst et al. (1998) \\
\hline $\begin{array}{l}\text { Mysid shrimp } \\
\text { Neomysis mercedis }\end{array}$ & $\begin{array}{l}\text { Resident of the LSZ, most abundant in summer. Omnivore, increasingly } \\
\text { carnivorous with development, preying on copepods and rotifers. }\end{array}$ & $\begin{array}{l}\text { Siegfried \& Kopache } \\
\text { (1980) }\end{array}$ \\
\hline $\begin{array}{l}\text { Bay shrimp } \\
\text { Crangon franciscorum }\end{array}$ & $\begin{array}{l}\text { Adults reproduce mainly in coastal ocean, young move into the estuary in } \\
\text { spring to rear in shallow areas. Epibenthic predators on mysids, amphipods } \\
\text { and mollusks. }\end{array}$ & $\begin{array}{l}\text { Hatfield (1985), Wahle } \\
\text { (1985), Emmett et al. (1991) }\end{array}$ \\
\hline $\begin{array}{l}\text { Starry flounder } \\
\text { Platichthys stellatus }\end{array}$ & $\begin{array}{l}\text { Adults spawn in winter, larvae and juveniles move far into the estuary in spring } \\
\text { to rear. Larvae planktivorous, juveniles consume benthic and epibenthic prey. }\end{array}$ & Emmett et al. (1991) \\
\hline $\begin{array}{l}\text { Pacific herring } \\
\text { Clupea pallasi }\end{array}$ & $\begin{array}{l}\text { Adults migrate from ocean to lower estuary in winter to spawn on solid substrate } \\
\text { or vegetation. Young rear through summer in estuary feeding on zooplankton. }\end{array}$ & Emmett et al. (1991) \\
\hline $\begin{array}{l}\text { American shad } \\
\text { Alosa sapidissima }\end{array}$ & $\begin{array}{l}\text { Anadromous, adults spawn in spring, larvae and juveniles rear in estuary feeding } \\
\text { on zooplankton. }\end{array}$ & Emmett et al. (1991) \\
\hline $\begin{array}{l}\text { Delta smelt } \\
\text { Hypomesus transpacificus }\end{array}$ & $\begin{array}{l}\text { Estuarine resident, adults spawn in winter, larvae and juveniles rear in and near } \\
\text { the LSZ, feeding on copepods and other small zooplankton. A federal and state } \\
\text { threatened species. }\end{array}$ & Moyle et al. (1992) \\
\hline $\begin{array}{l}\text { Longfin smelt } \\
\text { Spirinchus thaleichthys }\end{array}$ & $\begin{array}{l}\text { Anadromous, adults spawn at age } 2 \text { in winter, larvae rear in and near the LSZ, } \\
\text { juveniles farther seaward, feeding on copepods and other small zooplankton. }\end{array}$ & Emmett et al. (1991) \\
\hline $\begin{array}{l}\text { Sacramento splittail } \\
\text { Pogonichthys macrolepidotus }\end{array}$ & $\begin{array}{l}\text { Adults spawn in early spring on riverine flood plains. Juveniles rear in fresh to } \\
\text { brackish water, feeding on a variety of aquatic invertebrates. }\end{array}$ & Sommer et al. (1997) \\
\hline $\begin{array}{l}\text { Striped bass } \\
\text { Morone saxatilis }\end{array}$ & $\begin{array}{l}\text { Anadromous, adults spawn in spring, larvae and juveniles rear in the LSZ, } \\
\text { feeding on copepods and switching to mysids and amphipods. }\end{array}$ & $\begin{array}{l}\text { Turner \& Chadwick } \\
\text { (1972), Stevens et al. (1985) }\end{array}$ \\
\hline
\end{tabular}

November and twice monthly (once monthly since 1994) from April to October, 1972 to 1999 (Orsi \& Mecum 1986, 1996, Kimmerer \& Orsi 1996). Chl a concentration was obtained from 1975 to 1999 from the IEP zooplankton and water quality (Lehman 1992) monitoring programs, which used the same methods and were combined in 1995. Data were analyzed for 2 salinity ranges: 0.5 to 6 psu (LSZ, Kimmerer et al. 1998) and 6 to 20 psu; and 2 seasons: spring (March to May) and summer (June to October). The salinity ranges were based on faunal breaks determined in previous analyses (e.g. Kimmerer et al. 1998). Data were analyzed by salinity range rather than geographic location because planktonic species in brackish regions of estuaries vary most strongly by salinity (Laprise \& Dodson 1994, Kimmerer et al. 1998).

Seasons were selected to correspond roughly with larval and juvenile stages of the fishes of interest, and the availability of data from the selected salinity ranges. Analysis of intra-seasonal patterns is described below. The log-transformed data within each salinity range were averaged within months and then within seasons.

Zooplankton data included abundance of the rotifer Synchaeta bicornis, the mysid Neomysis mercedis, and adults of the copepod Eurytemora affinis, all averaged over stations in the LSZ. Rotifers and mysids are uncommon in spring and their abundance was averaged only over summer months. Abundance of the copepod Acartia spp., not identified to species in the monitoring program but comprising at least 3 species (unpubl. data), was analyzed from stations at a salinity of 6 to $20 \mathrm{psu}$.

For chl a and copepod abundance, for which data were available over several months, I performed a principal components analysis (PCA) of annual patterns by month to determine modes of variability. Following Jassby (1999) and Jassby et al. (2002), I constructed a table of means by month (column) and year (row), then treated each column as a separate variable in the PCA. In contrast to chl $a$ in the Delta (Jassby et al. 2002), which had separate spring and summer modes of variability, only a single mode dominated the patterns in the data presented here.

Abundance indices for juvenile life stages of fish and shrimp were obtained from IEP reports based on 3 routine surveys. The fall midwater trawl survey obtained data during 1967 and 2000 (except 1974 and 1979), monthly from September to December at 57 to 113 (median 88) stations in the northern estuary. Ten min oblique tows from near the bottom to the surface were 
taken with a $3.7 \mathrm{~m}$ square trawl with a variable mesh body $(20.3$ to $2.5 \mathrm{~cm}$ ) and a $1.3 \mathrm{~cm}$ stretch mesh cod end. The annual midwater trawl (MWT) abundance index was calculated for each survey as the mean catch per tow over each of 17 regions multiplied by the volume in that region, summed over all regions and then over all months.

The San Francisco Bay study (Armor \& Herrgesell 1985) took samples monthly all year during 1980 and 2000, except in winter months since 1989, using both an otter trawl and a MWT. Abundance indices were calculated similarly to those from the fall MWT survey using the otter trawl for demersal species and the MWT for other species.

Abundance indices for striped bass Morone saxatilis and delta smelt Hypomesus transpacificus were obtained from a summer townet survey (Turner \& Chadwick 1972). From 1959 to 2000 (except for 1966), 2 to 5 surveys were conducted at approximately $2 \mathrm{wk}$ intervals starting in June. The median number of stations used was 27. The striped bass YOY index was interpolated to the time when the mean size of the young striped bass in the catch was $38 \mathrm{~mm}$. The delta smelt index was calculated from the mean abundance in the 2 surveys used to determine striped bass abundance (Miller 2000).
Abundance of Sacramento splittail was incremented by 1 , and that of starry flounder by 10 , to account for 0s in log transformation as for zooplankton. Data for starry flounder were abundance at Age-1, related to flow conditions during the previous year, because Age-0 starry flounder are not collected reliably. Otherwise, data were for Age-0 fish and shrimp, related to flow conditions during the same year.

Abundance indices of striped bass and Pacific herring were autocorrelated because of effects of spawning stock size; therefore, indices of early survival were used instead of abundance indices. Abundance of young striped bass has been affected by declining egg production due to a shrinking adult population; hence, a survival index for young striped bass was calculated for 1969 to 1994 (Kimmerer et al. 2001). This index is the log ratio of the summer townet index of young striped bass (Turner \& Chadwick 1972) to potential egg production by the adult population. Potential egg production was calculated by multiplying estimates of age-specific fecundity by abundance at age based on Petersen mark-recapture estimates (Stevens et al. 1985, Kimmerer et al. 2000). Corrections were also made for the fraction of each age class that is mature and that actually migrates to the spawning ground (Stevens et al. 1985).

Table 2. Data sources used in this study

\begin{tabular}{|c|c|c|c|}
\hline Data type & Frequency & Source & Variables \\
\hline $\begin{array}{l}\text { Chlorophyll } \\
\text { (chl a) }\end{array}$ & $\begin{array}{l}\text { Monthly } 1975 \text { to } \\
1999\end{array}$ & $\begin{array}{l}\text { Water quality and } \\
\text { zooplankton monitoring } \\
\text { programs }\end{array}$ & $\begin{array}{l}\text { Whole chl } a \text { averaged over all stations } \\
\text { in the low salinity zone (LSZ) } \\
\text { (salinity } 0.5 \text { to } 6 \text { ) and in salinity } 6 \text { to } \\
20 \text {, separately for spring (March to } \\
\text { May) and summer (June to October). }\end{array}$ \\
\hline Zooplankton & $\begin{array}{l}1 \text { to } 2 \mathrm{mo}^{-1} \text { March } \\
\text { to November } \\
1972 \text { to } 1999\end{array}$ & $\begin{array}{l}\text { Zooplankton monitoring } \\
\text { programs (Orsi \& Mecum 1986) }\end{array}$ & $\begin{array}{l}\text { Three zooplankton taxa in the LSZ: } \\
\text { rotifers (Synchaeta bicornis) and mysids } \\
\text { (Neomysis mercedis) in summer and } \\
\text { copepods (Eurytemora affinis) separately } \\
\text { in spring and summer. Also Acartia spp. } \\
\text { in spring and summer in } 6 \text { to } 20 \text { psu. }\end{array}$ \\
\hline $\begin{array}{l}\text { Midwater trawl } \\
\text { (MWT) indices }\end{array}$ & $\begin{array}{l}\text { Annual } \\
1967 \text { to } 2000\end{array}$ & $\begin{array}{l}\text { Fall MWT } \\
\text { survey }\end{array}$ & $\begin{array}{l}\text { Indices of abundance and salinity data } \\
\text { for longfin smelt, American shad, } \\
\text { Sacramento splittail. }\end{array}$ \\
\hline $\begin{array}{l}\text { Annual abundance } \\
\text { indices }\end{array}$ & $\begin{array}{l}\text { Annual } \\
1980 \text { to } 2000\end{array}$ & $\begin{array}{l}\text { San Francisco Bay Study } \\
\text { (Armor \& Herrgesell 1985) }\end{array}$ & $\begin{array}{l}\text { Indices of abundance for bay shrimp, } \\
\text { Pacific herring, starry flounder; salinity } \\
\text { data for fish and shrimp }\end{array}$ \\
\hline $\begin{array}{l}\text { Striped bass and } \\
\text { delta smelt Index }\end{array}$ & $\begin{array}{l}\text { Annual } \\
1959 \text { to } 2000\end{array}$ & $\begin{array}{l}\text { Summer tow net survey } \\
\text { (Turner \& Chadwick 1972) }\end{array}$ & $\begin{array}{l}\text { Indices of abundance interpolated to } \\
\text { mean length of } 38 \mathrm{~mm} \text { for striped bass; } \\
\text { abundance in the last } 2 \text { surveys for } \\
\text { delta smelt. }\end{array}$ \\
\hline $\begin{array}{l}\text { Potential striped } \\
\text { bass egg production }\end{array}$ & $\begin{array}{l}\text { Annual } \\
1968 \text { to } 1994\end{array}$ & $\begin{array}{l}\text { Adult striped bass survey, } \\
\text { fecundity estimates } \\
\text { (Stevens et al. 1985) }\end{array}$ & $\begin{array}{l}\text { Total egg production estimate } \\
\text { based on abundance estimate } \times \\
\text { age-specific fecundity } \times \\
\text { maturity/migration corrections }\end{array}$ \\
\hline $\begin{array}{l}\text { Herring egg } \\
\text { production }\end{array}$ & $\begin{array}{l}\text { Annual } \\
1973 \text { to } 2000\end{array}$ & $\begin{array}{l}\text { Annual egg survey (Spratt 1981, } \\
\text { Watters \& Oda 2001) }\end{array}$ & $\begin{array}{l}\text { Estimate of eggs based on surveys } \\
\text { of spawning grounds }\end{array}$ \\
\hline
\end{tabular}


I calculated a survival index for Pacific herring as the ratio of the juvenile index from the Bay study MWT survey to egg abundance. Egg abundance was estimated by the Department of Fish and Game separately for eggs attached to vegetation, intertidal hard substrate and pier pilings, then combined into a single annual estimate (Watters \& Oda 2001, based on Spratt 1981).

The hypotheses tested for each taxon were: (1) the response variable is related to $\mathrm{X}_{2}$; and (2) the response variable changed between 1987 and 1988. The latter change would be consistent with an effect of the clam Potamocorbula amurensis if its filtration rate underwent a step change from 0 before to a high value after that time. This seems to have been the case: clam abundance in Suisun Bay went from 0 to over $2000 \mathrm{~m}^{-2}$ in 1 mo (Alpine \& Cloern 1992) and has since exceeded $1400 \mathrm{~m}^{-2}$ in $1 / 2$ of the samples taken in Suisun and San Pablo Bay year-round (IEP data). Routine benthic monitoring includes too few stations for an estimate of interannual variability of clam abundance adequate for detailed testing of effects of clams on the pelagic food web. In addition, it does not report size of clams, which is needed to estimate filtration rate. Estimates of community filtration rates in Suisun Bay suggest that Potamocorbula amurensis is probably responsible for the continued low chl a concentrations there (J. Thompson, US Geological Survey, pers. comm.).

The fundamental statistical model fitted to the abundance data was a regression on $\mathrm{X}_{2}$ with a dummy variable YearCat, which was 0 for years up to 1987 and 1 thereafter. The model was then:

$$
Y_{i}=\alpha \mathrm{X}_{2 i}+\beta \text { YearCat }_{i}+\gamma \mathrm{X}_{2 i} \times \text { YearCat }_{i}+\varepsilon_{i}
$$

where $Y$ is the log-transformed abundance or survival index or value, $\alpha, \beta$ and $\gamma$, are parameters to be estimated, $\varepsilon_{i}$ is the error term, and subscript $i$ refers to year. This model was refined as necessary. Where the interaction term was significantly different from 0 , the data set was broken into 2 parts corresponding to YearCat for separate estimates of $\alpha$. When $\gamma$ was not different from 0 , and in all cases to estimate $\beta$, the model was fitted without the interaction term.

To illustrate the range of habitat used by the species considered here, salinity ranges were determined for each species of fish and shrimp from the San Francisco Bay study, which has the best coverage of the salinity range of the sampling programs. Mean abundance was calculated for each of 25 salinity ranges or 'bins' containing approximately equal numbers of samples. Data from the zooplankton survey were treated similarly, except the salinity bins had linearly decreasing numbers of samples with increasing salinity to account for the heavy weighting of sampling toward freshwater.
Minimum bin size was 25 samples in that case. Mean salinity and mean abundance by bin were calculated, and the 25th, 50th and 75th percentiles of relative abundance in salinity space were interpolated.

Trawl sampling is inefficient, and its efficiency can vary with turbidity (Rozas \& Minello 1997), which increases in the estuary under high flow conditions (Buchanan et al. 1995, Buchanan \& Schoellhamer 1996). Assessing this potential source of bias directly is difficult because turbidity also covaries with season, salinity, and particularly wind and tidal currents. To determine whether such bias was likely, I analyzed mean length of common fish species and proportion of adults in the shrimp catch, assuming that bias due to turbidity would be reflected both in lower catches and a smaller proportion of large individuals in samples from clearer water. Using only samples from which at least 20 individuals had been measured for each species, with data aggregated over seasons of high abundance and similar size distributions, I then determined regressions of mean length versus secchi depth as a measure of turbidity.

Data analyses relied on an exploratory approach with an emphasis on graphical techniques (Cleveland 1973). Assumptions of normality, homoscedasticity, lack of autocorrelation in residuals and lack of excessive influence of single points were tested by examining standard plots of residuals including autocorrelation functions. Cases in which some points had high influence were examined further using robust techniques (Venables \& Ripley 1997); the few cases where the results were qualitatively different from the unweighted linear model are discussed below. In the initial analysis of delta smelt abundance, there was evidence that the fitted model was inappropriate, as determined by plots of residuals. Further analysis was done with this species to determine a more suitable model using tree regression to determine the timing of change in abundance. However, for comparability most of the discussion addresses the model described above.

\section{RESULTS}

Salinity ranges of most species were broad (Fig. 2). The median salinity values ranged from 0.3 for American shad to 19 for Pacific herring. All but 3 of these species had median salinity between 0.5 and 6 , i.e. their distributions overlapped substantially with the LSZ, but large parts of these populations are outside of the LSZ. Trophic interactions are likely among some of these species by virtue of their spatial and temporal overlap as well as feeding modes (e.g. Fig. 3 in Jassby et al. 1995). 


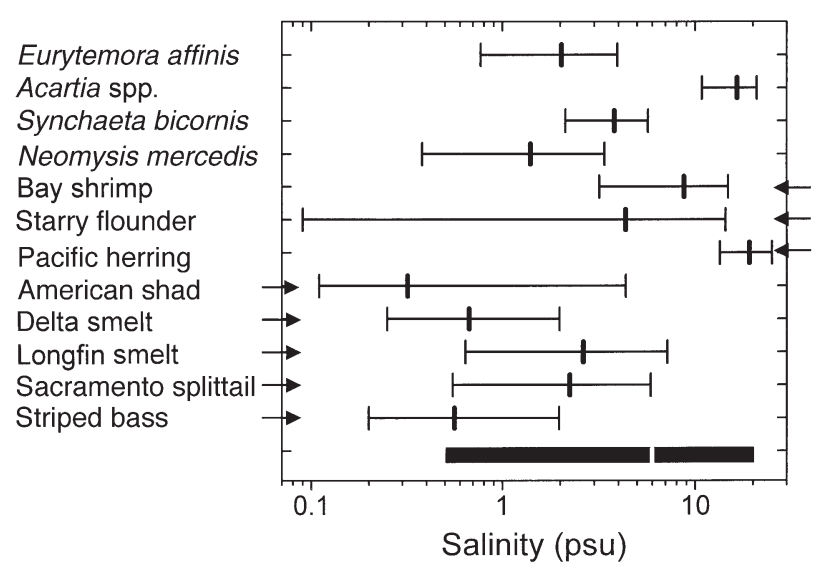

Fig. 2. Salinity ranges of taxa examined. For each taxon, the horizontal line gives the 25th, 50th and 75th percentiles of the distribution of abundance with respect to salinity. Salinity is plotted on a log scale, which emphasizes freshwater and underemphasizes the large spatial extent of higher salinity water and distribution of, e.g. Pacific herring. Arrows indicate the direction of ontogenetic movement. Shaded bars at the bottom indicate the 2 salinity ranges for chlorophyll analyses

The time course of freshwater flow into the estuary and $\mathrm{X}_{2}$ indicates several high flow periods and several droughts (Fig. 3). The highest, i.e. most landward, $\mathrm{X}_{2}$ values occurred during a severe drought in 1976 to 1977, and an extended drought lasting from 1984 through 1992 except for March 1986.

Chl a concentration and copepod abundance showed single modes of variability based on the seasonal PCA (Table 3). The first PC and the mean annual values for each month were correlated with a coefficient of at least 0.64 (up to 0.99). The first PC showed a strong decline around 1987 and was unrelated to $\mathrm{X}_{2}$ (coefficients $\alpha$ and $\gamma$ in Eq. [1] not significant, $p>0.1$ ).

Time courses of the response variables show rather consistent declines in the late 1980s among the lower trophic levels, particularly in summer (Fig. 4). Although the specific temporal pattern varied among responses, chl $a$ and abundance of 4 zooplankton taxa were lower after 1987 than before. This contrasts with the overall pattern among fish and shrimp (Fig. 5). Few of these showed a pattern of annual abundance or

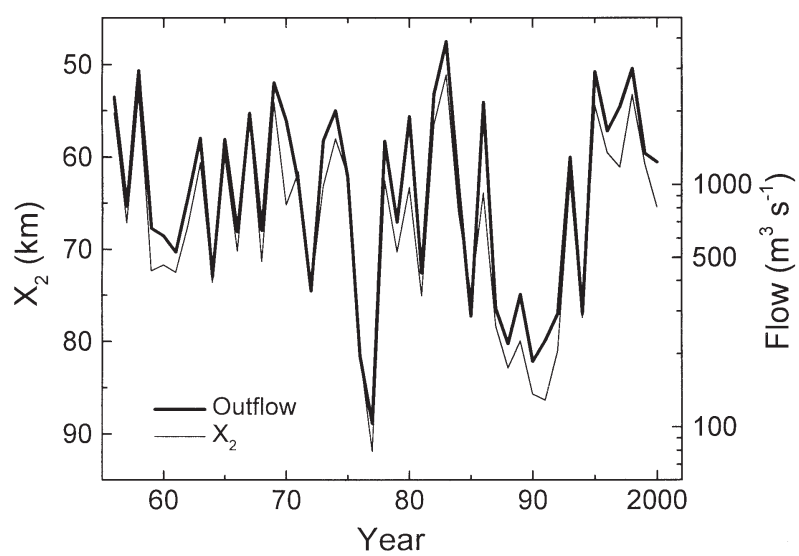

Fig. 3. Time series of $\mathrm{X}_{2}$ (distance up the axis of the estuary to the 2 psu isohaline, thin line, left axis, scale reversed) and flow (heavy line, right axis, log scale), annual averages for January to June. Flow data from the California Department of

Water Resources; $\mathrm{X}_{2}$ calculated as in Jassby et al. (1995)

survival index that was consistently lower after 1987 than before, although delta smelt abundance was lower after 1981 than before (Fig. 5E).

A clear contrast also exists between the taxa in lower trophic levels, and the fish and shrimp in their relationships to $\mathrm{X}_{2}$ (Figs. 6, $7 \& 8$, Table 4). Taxa in lower trophic levels had generally weak responses to flow. With several exceptions discussed below, fish and shrimp generally had strong relationships to $\mathrm{X}_{2}$ and relatively small changes between the 2 periods. With the exception of delta smelt, the patterns of change of populations of higher and lower trophic levels clustered separately (Fig. 6).

Details of the patterns summarized in Fig. 6 are presented in Table 4 and Figs. 7 \& 8. Chl $a$ in the LSZ has never had a strong relationship with $\mathrm{X}_{2}$, although the relationship in the summer data up to 1987 may be unimodal (Fig. 7B), as found by Jassby \& Powell (1994). Although the interaction term for spring chl $a$ in the LSZ was statistically significant, the slopes versus $\mathrm{X}_{2}$ were rather small both before and after 1987 (Table 4). The mean chl a value decreased after 1987 by about 3 -fold in spring and 4-fold in summer (Figs. 4A,B \&

Table 3. Results of principal components analysis on chlorophyll (chl a) concentration in 2 salinity ranges and abundance of 2 copepod species. In each case, only the first principal component explained a significant proportion of the variance

\begin{tabular}{|c|c|c|c|c|}
\hline \multirow[t]{2}{*}{ Variable } & \multicolumn{2}{|c|}{ Proportion variance (\%) } & \multirow[t]{2}{*}{ Months } & \multirow[t]{2}{*}{ Years } \\
\hline & PC1 & $\mathrm{PC} 2$ & & \\
\hline Chl $a, 0.5-6 \mathrm{psu}$ & 78 & 11 & Mar to Oct & 1975-99 ('95 omitted) \\
\hline Chl $a, 6-20 \mathrm{psu}$ & 79 & 8 & Apr to Oct & 1975-99 ('95 omitted) \\
\hline Eurytemora affinis, $0.5-6 \mathrm{psu}$ & 88 & 5 & Mar to Oct & 1972-99 (all) \\
\hline Acartia spp., 6-20 psu & 80 & 12 & Apr to Oct & 1972-99 ('73, '74, '75 omitted) \\
\hline
\end{tabular}




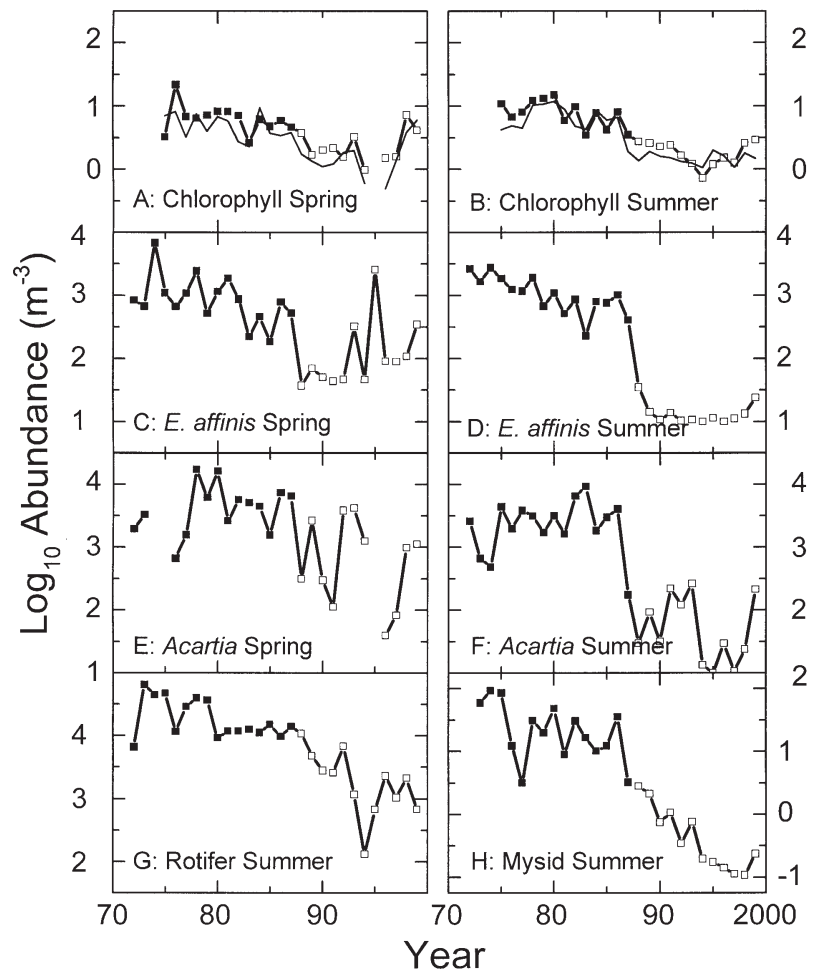

Fig. 4. Time course of plankton abundance measures. (๕) Data up to 1987 ; (口) 1988 to 1999 . All variables have been logtransformed and are on the same relative scale. For chlorophyll (A and B), symbols indicate data from the low salinity zone (LSZ) (0.5 to $6 \mathrm{psu}$ ) and thin lines data from 6 to $20 \mathrm{psu}$; the copepod Eurytemora affinis, the rotifer Synchaeta bicornis and the mysid Neomysis mercedis are from the LSZ. The copepod Acartia spp. is from 6 to 20 psu

$7 \mathrm{~A}, \mathrm{~B})$. The period up to 1987 was characterized by phytoplankton blooms that typically lasted most of the spring and summer, with long-term geometric mean chl $a$ around $10 \mathrm{~g} \mathrm{l}^{-1}$. After 1987, chl a values have been almost uniformly low through spring and summer except for 1 moderate spring bloom in 1998 (Fig. 4A). $\mathrm{Chl} a$ at higher salinity had a similar pattern to that in the LSZ, except for the lack of an interaction term in spring (Fig. 6, Table 4).

The abundance of the copepod Eurytemora affinis (Figs. 4C,D \& 7C,D) declined by about 7 -fold in spring and 7 -fold in summer after 1987. Springtime abundance had a significant interaction, forcing a split into the 2 time periods, with the post-clam period having a significant negative relationship with $\mathrm{X}_{2}$ (Table 4). The copepod Acartia spp. (Figs. 4E,F \& 7E,F) declined by roughly the same amount as E. affinis. The $\mathrm{X}_{2}$ term in spring was not statistically significant, but this result was influenced by 2 low points in 1996 and 1997. This increased the error variance and may have obscured a slope of about -0.02 as determined by robust regression (Venables \& Ripley 1997). In summer, there was no effect of flow on Acartia abundance.
The rotifer Synchaeta bicornis is typically abundant in the LSZ in summer. Abundance was unrelated to $\mathrm{X}_{2}$ and declined about 11 -fold between the 2 time periods (Figs. 4G \& 7G). The mysid Neomysis mercedis (Figs. $4 \mathrm{H} \& 7 \mathrm{H}$ ) was previously abundant in the LSZ in summer but declined about 50 -fold after 1987 . The response of $N$. mercedis to $\mathrm{X}_{2}$ changed significantly between the 2 periods, with a negative slope through 1987 (higher at high flow) and a steep positive slope thereafter (Table 4).

Abundance patterns of Eurytemora affinis and Neomysis mercedis provide an incomplete picture because these species were at least partially replaced by other species of somewhat similar life history (Orsi \& Ohtsuka 1999). The decline in biomass of calanoid copepods and total mysids was much smaller than those for the single species indicated in Fig. 4. Thus, although there is a clear response of individual species to the step change after 1987, the change in the food environment for higher trophic levels was not so sharp, in spite of the large decline in chl $a$.

All of the fish and shrimp, except delta smelt, had negative relationships with $\mathrm{X}_{2}$, indicating higher abundance at high flow, and 2 of them had lower intercepts after 1987. The bay shrimp Crangon franciscorum (Figs. 5A \& 8A) had a significant relationship with $\mathrm{X}_{2}$ that had not appeared to change since 1988, although both the lowest and highest residuals around

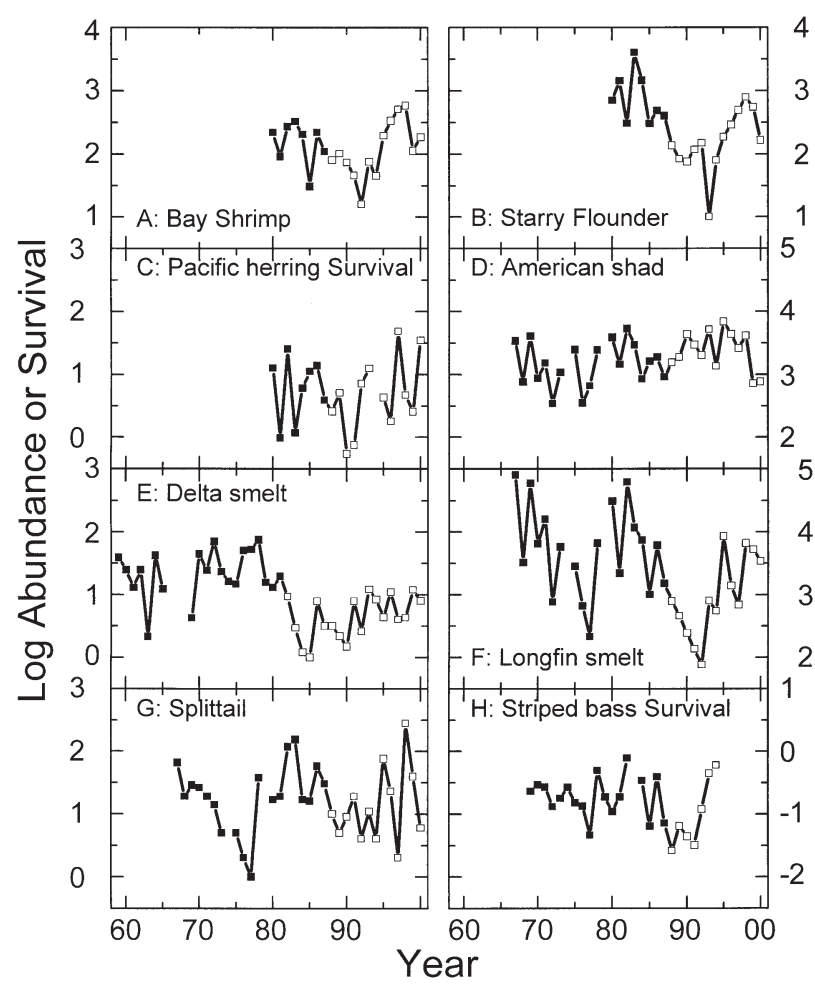

Fig. 5. Time course of fish and shrimp abundance indices or, where noted, survival indices. Details as for Fig. 4 


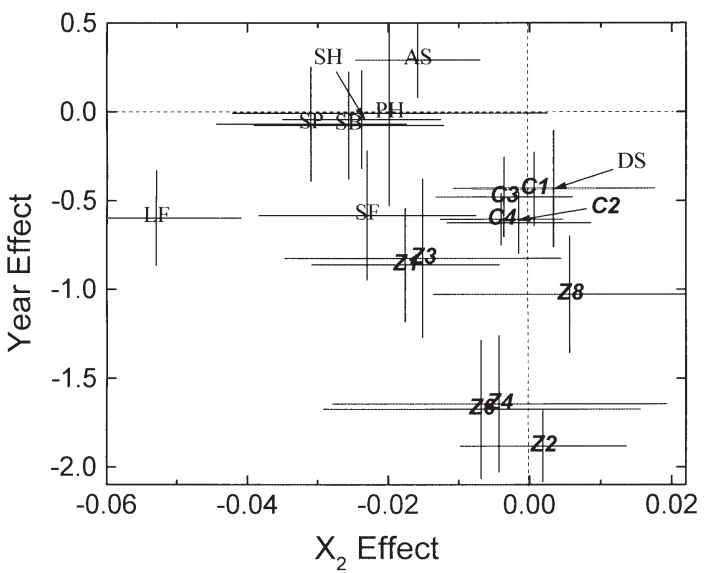

Fig. 6. Summary graph of responses to $\mathrm{X}_{2}$ and a step change after 1987. Each point represents the 2 parameter values $(\alpha$ for $\mathrm{X}_{2}$ and $\beta$ for YearCat) from Eq. (1), with the interaction term $\gamma$ set to 0 , on one of the variables from Figs. $4 \& 5$. Lower trophic level taxa are shown in bold. Note that some violations of assumptions of the analysis were accepted to allow all results to be plotted on a single graph (see models in Table 4). Lines giving $95 \%$ confidence limits around the parameter estimates may be underestimates in those cases. Solid arrows indicate labels moved for clarity. Variables are in order in which they appear in Figs. 3 \& 4: chlorophyll in the low salinity zone (LSZ) in spring (C1) and summer (C2), and at salinity of 6 to $20 \mathrm{psu}$ in spring (C3) and summer (C4); Eurytemora affinis in spring (Z1) and summer (Z2), Acartia spp. in spring (Z3) and summer (Z4), Synchaeta bicornis in summer (Z6), and Neomysis mercedis in summer (Z8); Bay shrimp (SH), starry flounder (SF), Pacific herring survival (PH), American shad (AS), delta smelt (DS), longfin smelt (LF), Sacramento splittail (SP) and striped bass survival (SB)

the $\mathrm{X}_{2}$ trend line were observed after 1988, indicating a possible transient response either to the change in the food web or to the extended drought from 1985 to 1992.

Starry flounder (Figs. 5B \& 8B) had a significant relationship with $\mathrm{X}_{2}$ that declined in intercept by nearly 4 -fold. Survival of Pacific herring (Figs. 5C \& 8C) had a weak relationship with $\mathrm{X}_{2}$ and no change over time. American shad had a weak but significant relationship to $\mathrm{X}_{2}$, but with a significant effect of time period by which abundance increased after 1987 (Fig. 5D).

The 2 smelt species had strikingly different patterns of abundance and response to $\mathrm{X}_{2}$. Delta smelt abundance index had no discernible relationship to $\mathrm{X}_{2}$ and appeared somewhat lower in abundance in the later time period than before (Figs. 5E \& 8E). However, tree regression and examination of plots (Fig. 5E) showed the data series to be most effectively divided between 1981 and 1982 rather than 1987 and 1988. Analysis as in Eq. (1) but with a step change between 1981 and 1982 had a significant interaction; subsequent regressions on the data from the 2 time periods showed a pos- itive relationship with $\mathrm{X}_{2}$ during the period up to 1981 and a negative but non-significant relationship from 1982 and 2000. By contrast, longfin smelt abundance index (Figs. 5F \& 8F) had the strongest relationship with $\mathrm{X}_{2}$ and a 4 -fold decline after 1987, with no significant change in slope (interaction term $0.018 \pm 0.022$, $\mathrm{p}>0.1$ )

Abundance of Sacramento splittail (Figs. 5G \& 8G) and survival of striped bass from egg to YOY (Figs. 5H \& $8 \mathrm{H}$ ) varied negatively with $\mathrm{X}_{2}$ and had no discernible change following 1987.

Size distributions of fish and proportion of adult shrimp in catches were analyzed for potential effects of water clarity for several species. Data were obtained from the Bay study for Pacific herring, longfin smelt and bay shrimp in April to July, and striped bass in July to September, and from the fall midwater trawl survey for American shad, longfin smelt and striped bass. In no case was the slope of a linear regression of mean length (or proportion adults in shrimp catch) versus log of secchi depth significantly negative, and several were significantly positive $(p<0.05$, linear regressions). This suggests that water clarity did not have a substantial effect on catchability by size, and relation-

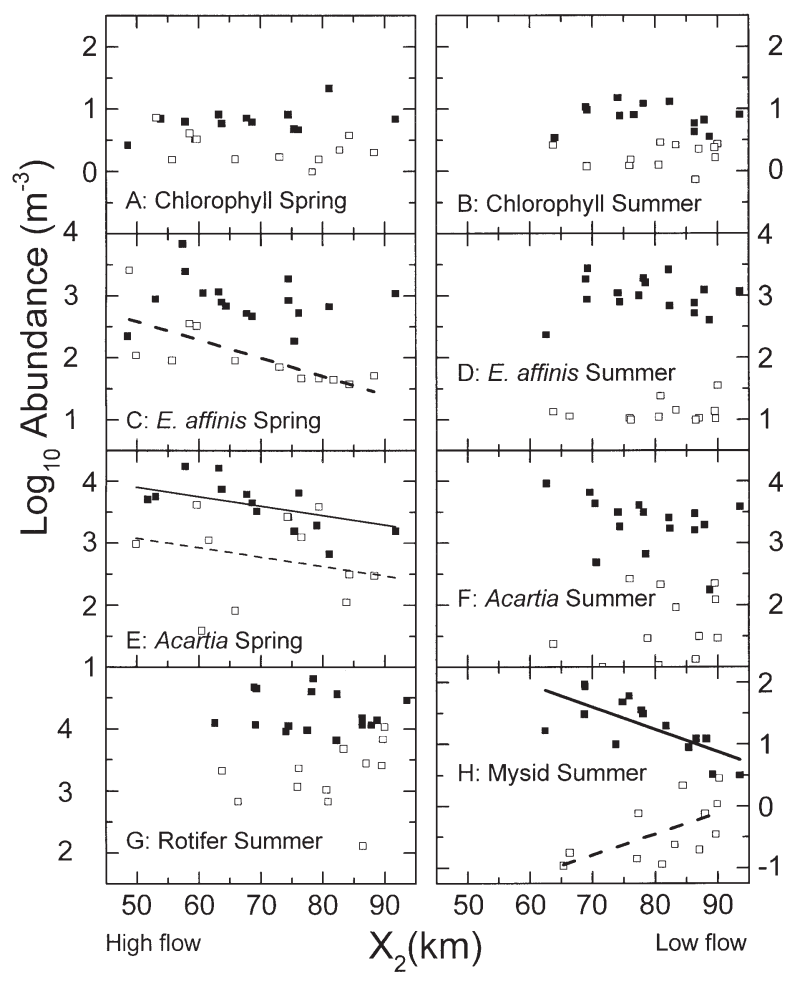

Fig. 7. Plankton abundance plotted against $\mathrm{X}_{2}$ (as for Fig. 4). (घ) and lines, data up to 1987; ( $\square$ ) and dotted lines, 1988 to 1999. Lines are provided only when statistically significant except for thin lines for Acartia spp. in spring (Panel E) (see statistics in Table 4). All variables have been log-transformed and are on the same relative scale 


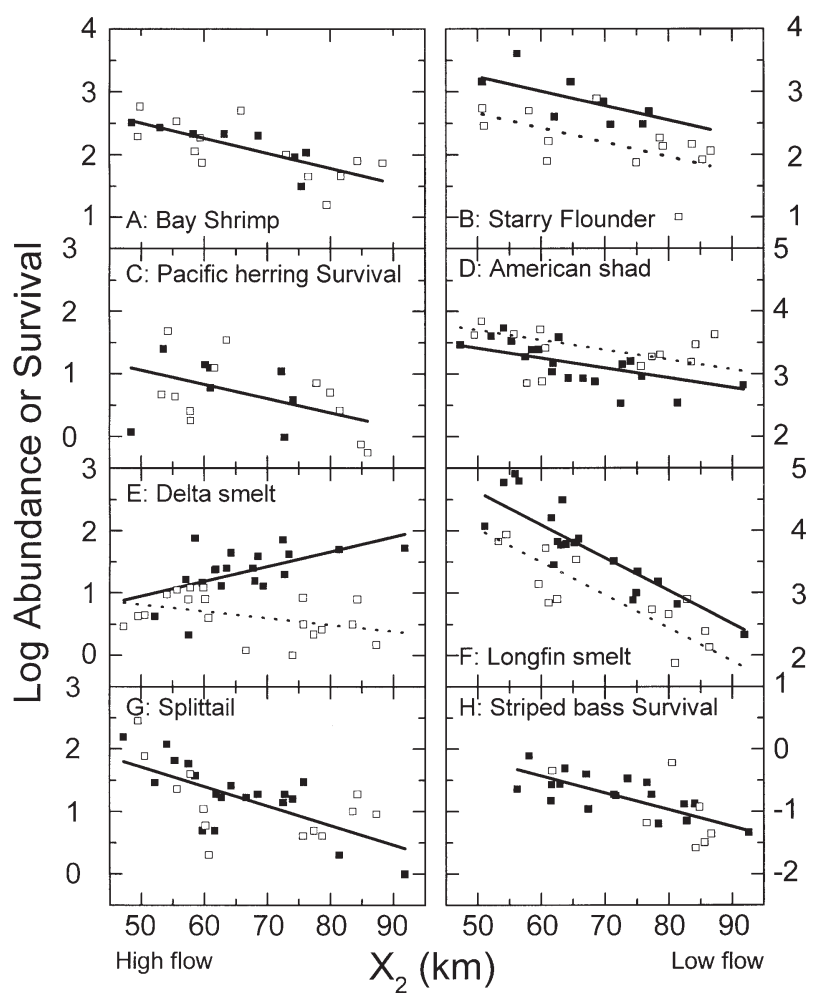

Fig. 8. Timescale of fish and shrimp abundance or, where noted, survival indices. Details as for Fig. 4. Regression statistics in Table 4. Taxa as for Fig. 5

ships of abundance to flow were likely not due to covariation of water clarity with both flow and catchability of the fish and shrimp.

\section{DISCUSSION}

The results presented here contrast with findings from other estuaries. Several mechanisms have been reported for positive effects of flow on populations (Drinkwater \& Frank 1994), including bottom-up effects due to nutrient stimulation (Aleem 1972, Sutcliffe 1972, 1973, but see Sinclair et al. 1986) or increased stratification with flow (Skreslet 1997), and suppression of predators on benthos by low salinity (Wilber 1992, Livingston et al. 2000). Catch rates of several fishery species were related to freshwater flow in an Australian estuary, although much of that relationship may have been due to vulnerability of the fish rather than population size (Loneragan \& Bunn 1999). As discussed below, none of these mechanisms is consistent with the data from the San Francisco Estuary. In addition, negative effects of freshwater flow on estuarine biota reported elsewhere (Deegan 1990, Kaartvedt \& Aksnes 1992, Livingston et al. 1997, Howarth et al. 2000) were nearly absent in estuarine-dependent spe- cies from the San Francisco Estuary. Abundance of marine species within the San Francisco Estuary may respond negatively to flow due simply to seaward displacement of their habitat, and therefore, population centers; however, this would be a distributional rather than a population response. Negative effects apparently due to osmotic stress have been observed in the benthos (Nichols et al. 1990), but pelagic organisms are able to move with the water and may be relatively unaffected by salinity fluctuations (Laprise \& Dodson 1993).

\section{Mechanisms for flow effects}

Bias is an unlikely explanation for the flow effects reported here. The most likely source of bias is increasing catchability with increasing turbidity (Rozas \& Minello 1997). However, turbidity depends mainly on tidal currents and wind, and is affected by freshwater flow mainly during extreme flow events. For example, suspended solids concentrations throughout the estuary were not much different between 1994, a drought year, and 1995, a high-flow year, except during flow peaks (Buchanan et al. 1995, Buchanan \& Schoellhamer 1996). Furthermore, mean length of common fish species or proportion of adult bay shrimp did not increase with turbidity as measured by secchi disk.

Although mechanisms behind the abundance flow relationships in higher trophic levels cannot be deduced from correlative analyses, these mechanisms are unlikely to arise from effects occurring at the base of the food web. A simplified view of the food web of the northern San Francisco Estuary (Fig. 9) illustrates the alternative causal pathways between physical forcing, particularly freshwater flow and biological responses. For freshwater flow to influence fish and shrimp through the food web (Fig. 9, Mechanisms 1 to 3 , and 4 for zooplankton) would require first that lower trophic levels have positive responses to flow, and that these responses propagate up the food web. Neither of these mechanisms is supported by the results presented here. Taxa in lower trophic levels either did not respond to flow, or they responded inconsistently by season, or with different slopes up to versus after 1987. Most taxa at higher trophic levels, which feed mainly on copepods and mysids during early life, had positive relationships to flow that did not change in slope after 1987, although several changed in intercept, 2 negatively and 1 positively. The large change noted for delta smelt (Fig. 8E, Table 4) apparently occurred well before the step change at the base of the food web (Fig. 5E). Thus, the flow response at higher trophic levels was largely uncoupled from variability in lower trophic levels. 


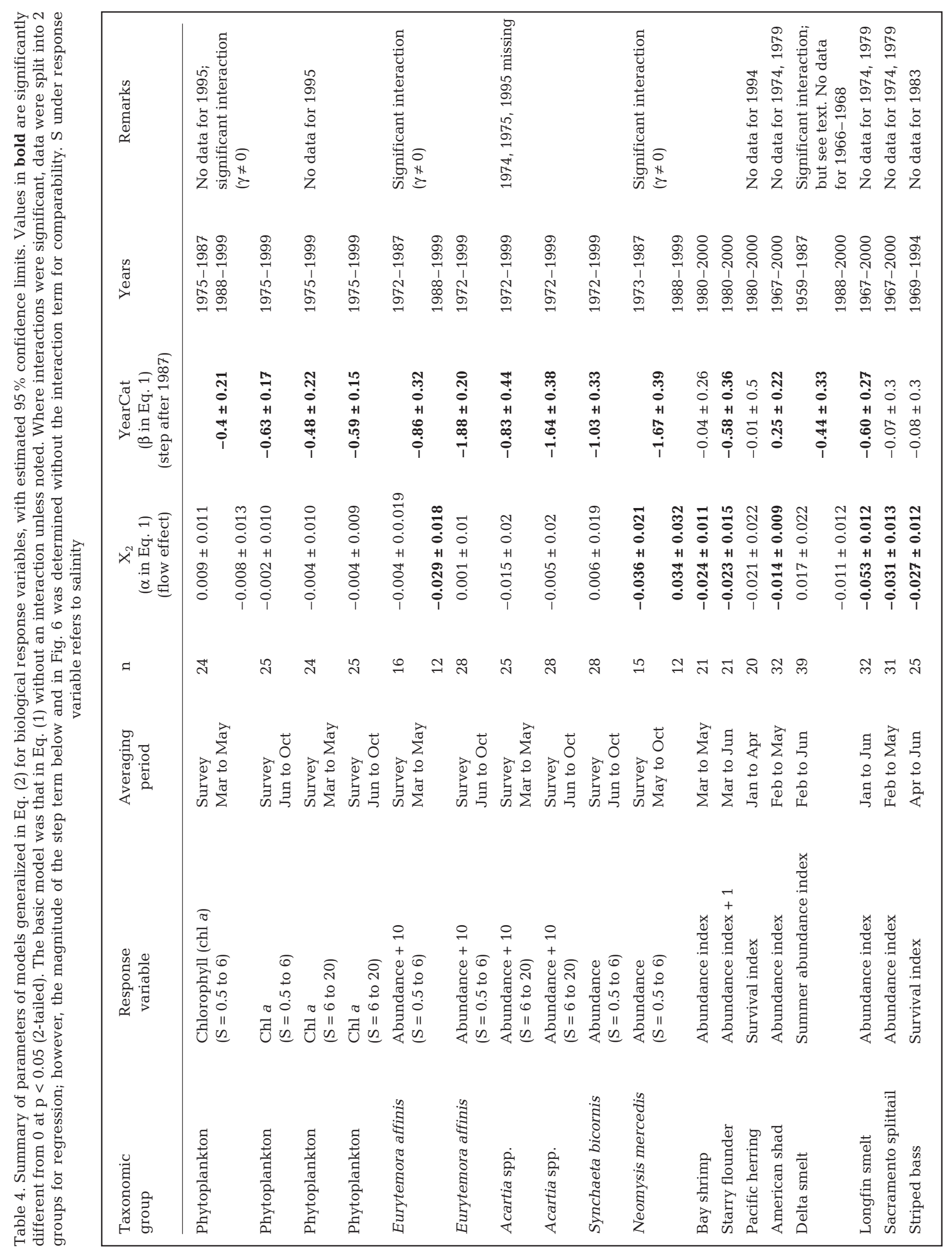




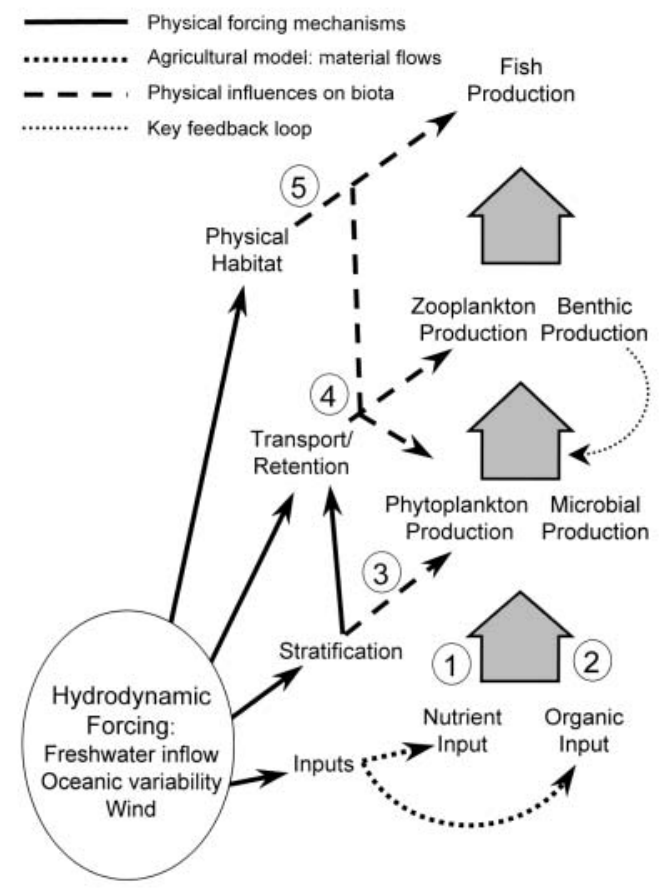

Fig. 9. Simplified food web for the San Francisco Estuary. Numbers indicate causal pathways for mechanisms of flow effects discussed in the text. Wide arrows indicate material flow, all others indicate causal pathways. In general, hydrodynamic forcing affects the physical environment (solid arrows), which then has various mechanisms for influences on the biotic environment (dotted and dashed lines). The feedback loop indicated on the right represents the influence of the clam Potamocorbula amurensis on the flow of energy from primary producers to both the zooplankton and the benthos

Additional information also fails to support Mechanisms 1 to 3 (Fig. 9). According to the agricultural model (Nixon et al. 1986), increasing nutrient or organic inputs with increasing flow results in stimulation that propagates to higher trophic levels (Fig. 9, Mechanisms 1 and 2). That model would require a causal chain by which increased nutrient input with high flow resulted in higher phytoplankton production and biomass, with increases subsequently passed up through the food web. However, phytoplankton production in the San Francisco Estuary is most commonly limited by light rather than nutrients (Arthur \& Ball 1979, Cole \& Cloern 1984, Cloern 1999), and nutrient concentrations in the northern estuary are generally high (Hager \& Schemel 1992).

Phytoplankton blooms can also occur through stratification, which may increase with freshwater flow (Fig. 9, Mechanism 3; Cloern 1991, Skreslet 1997). However, in the San Francisco Estuary, such blooms appear to be ephemeral (Cloern 1991). The PCA results suggested the principal mode of variability of chl $a$ and copepod abundance in all months was the step after 1987. Furthermore, chl a concentration showed little response to freshwater flow either before or after Potamocorbula amurensis became abundant (Fig. 7A,B). In the Delta, in spring, chl a actually decreased with increasing flow, apparently because of decreasing residence time (Jassby et al. 2002). Thus, there is no evidence that seasonally averaged phytoplankton biomass responded to flow through either increased nutrient loading or increased stratification with flow.

Exogenous organic carbon may provide important energy supplies to estuaries (e.g. Smith \& Hollibaugh 1993, Kemp et al. 1997). The supply rate of organic carbon to a brackish estuary increases with increasing freshwater flow, mainly because of river-borne inputs (Jassby et al. 1993, 1995). Most of the bioavailable carbon in the San Francisco Estuary arises from phytoplankton (Jassby et al. 1993, Canuel et al. 1995, Jassby \& Cloern 2000). Although biomass in the Delta decreased with increasing flow in spring, loading still increased (Jassby et al. 1993, 2002 Fig. 8A). With an increase in the supply rate of bioavailable carbon with flow, bacterial production could increase with flow (Fig. 9, Mechanism 2). There is no information on the response of bacterial production to flow, although bacterial abundance may have declined following the spread of Potamocorbula amurensis, which is capable of filtering bacteria from the water column (Werner \& Hollibaugh 1993, Hollibaugh \& Wong 1996). In any case, for the stimulation of bacterial production due to increased carbon loading to reach higher trophic levels would require equivalent levels of response to flow in the intermediate trophic steps, i.e. zooplankton and particularly rotifers (Holst et al. 1998); however, this was not observed.

It is unlikely that the lower trophic levels responded to flow in production but not in biomass. Jassby et al. (2002) argued that primary production in the Delta followed trends in chl a concentration, and the same argument holds for Suisun and San Pablo Bays. Reproductive rate of the copepod Eurytemora affinis did not vary with flow or chl $a$, nor did it change after the arrival of Potamocorbula amurensis (Kimmerer et al. 1994). Similarly, no changes were detected in fecundity of Neomysis mercedis (Orsi \& Mecum 1996). Data are unavailable to estimate production of other planktonic taxa, but without an increase in food supply with flow, there is no reason to expect specific growth rate to increase with increasing flow for any of these taxa.

The contrast between results for the lower and higher trophic levels (Fig. 6, see below) suggests that different mechanisms influence abundance patterns of these groups. There is evidence of bottom-up effects in the pelagic food web propagating from the decline in phytoplankton through rotifers, copepods and mysids, 
and into starry flounder and longfin smelt, but apparently leaving other fish and shrimp unaffected. However, these bottom-up effects appear unrelated to the $\mathrm{X}_{2}$ relationships of fish and shrimp. This implies that mechanisms underlying responses of fish and shrimp may occur more directly, such as through changes in physical habitat (Fig. 9). To assess these effects will require further research, since the statistical analyses reported here are insufficient to establish causes.

Bennett \& Moyle (1996) described several alternative mechanisms by which flow could influence young stages of fish. For few species are data available to support or reject these mechanisms, although the list of possible mechanisms for any 1 species can be narrowed. The mechanisms underlying flow effects probably operate in the region or range of salinity where each species is found during early life (Fig. 2). For example, floodplain inundation may favor splittail recruitment through improved access to shallow foraging, spawning or rearing habitat (Fig. 9, Mechanism 5; Sommer et al. 1997). This mechanism could also affect American shad and some other species in freshwater, but is unlikely to affect those found mainly in brackish to saline water. Species such as bay shrimp, starry flounder and herring could be affected by changes in gravitational circulation in the seaward reaches of the estuary, since these species hatch in or near the ocean, and presumably use net landward bottom currents to move into and up the estuary. This mode of recruitment is common in decapod crustaceans and flatfish (e.g. Cronin \& Forward 1979, Harden Jones et al. 1979, Forbes \& Benfield 1986, Christy \& Morgan 1998).

The main point, though, is that the mechanisms underlying flow effects on each of the species are apparently different. This implies in turn that these mechanisms are unlikely to be general, but rather that they arise through specific features of the San Francisco Estuary that may not exist in other estuaries. If true, this result would have the unfortunate consequence of reinforcing the emphasis on the particular in studies of estuarine ecology.

Livingston (1997) and Livingston et al. (1997) used a 10 to 13 yr data set in a correlative analysis to determine effects of freshwater flow on trophic structure of the food web of Apalachicola Bay, Florida. Lower trophic levels were affected directly by river flow, while higher trophic levels were affected mainly by biological interactions. The principal basis for these effects was an increase in water clarity during a prolonged drought, apparently causing an increase in primary production (Livingston et al. 1997). Thus, the mechanisms for effects of flow, and the overall responses of the food webs, appear to differ between Apalachicola Bay and the San Francisco Estuary. The common lesson to be learned from these 2 estuaries appears to be the complexity of the food webs (Livingston et al. 1997), whose response to rather dramatic forcing is difficult to interpret or generalize.

\section{Response of the food web to perturbation}

The introduction of Potamocorbula amurensis was accompanied by a number of rapid changes at the base of the food web. The decline in chl a concentration, which extended far into the Sacramento-San Joaquin delta (Jassby et al. 2002), suggests a substantial, system-wide loss of organic input. Although riverine sources of organic carbon are large, the supply of labile carbon to the estuary is dominated by phytoplankton (Jassby et al. 1993, 2002, Jassby \& Cloern 2000 ). Even before this decline, primary production in the San Francisco Estuary was at the low end of the range for estuaries (Boynton et al. 1982). Furthermore, evidence is growing that consumer organisms in the San Francisco Estuary are frequently and persistently food-limited (Foe \& Knight 1985, Orsi \& Mecum 1996, Mueller-Solger et al. 2002, author's unpubl. data).

Alternative consumers have partially replaced those existing before this event: for example, introduced copepods such as Pseudodiaptomus forbesi have taken the place of Eurytemora affinis (Kimmerer \& Orsi 1996), and introduced mysids have partially compensated for the loss of Neomysis mercedis (Modlin \& Orsi 1997). Potamocorbula amurensis itself is an additional source of food for a few species listed in Table 1, although it may have suppressed other benthic species (Nichols et al. 1990). Nevertheless, the general trend throughout the northern estuary has been toward decreased organic matter production and plankton abundance with time, particularly following the spread of $P$. amurensis.

The lack of response of certain fish and shrimp species to this change is somewhat surprising. The planktonic species comprise much of the food supply for larvae, juveniles and smaller adults of striped bass and other fish, and epibenthic shrimp in the estuary (Heubach et al. 1963, Sitts \& Knight 1979, Meng \& Orsi 1991, Bennett \& Moyle 1996, Nobriga 1998). For example, delta smelt larvae feed mostly on Eurytemora affinis and appear less able to feed on Pseudodiaptomus forbesi (Nobriga 1998), yet delta smelt did not appear to respond to the change in abundance of $E$. affinis. Similarly, striped bass feed on copepods in spring and summer, switching to mysids later in the year (Heubach et al. 1963); since P. forbesi does not become abundant until summer (Kimmerer \& Orsi 1996), there seems to be a gap in availability of food for striped bass, yet they appear not to have responded. A decline in carrying capacity in the estuary for striped bass 
occurs later in life when they start to consume mysids or small fish (Kimmerer et al. 2000).

Detailed comparisons of diets of fish and shrimp between the 2 time periods have not been made. Nevertheless, differences among the fish and shrimp in response to the downward shift in primary production do not appear to be related to dietary habits, or seasonal or spatial patterns. For example, bay shrimp and starry flounder both feed on benthic and epibenthic prey (Table 1), and both recruit from the ocean in spring, yet starry flounder declined and bay shrimp did not (Fig. 8A,B). The smelt species, American shad, and young striped bass all move down the estuary to brackish water as they develop, and all feed on plankton in open waters (Table 1), but only longfin smelt appeared to respond to the downward shift in production.

Thus, despite the apparently tight coupling between benthic grazing and pelagic production, trophic coupling within the pelagic food web of the San Francisco Estuary may be weak. Complex aquatic food webs in general may be weakly coupled (Strong 1992, Polis \& Strong 1996, Micheli 1999) and weak trophic interactions may stabilize food webs (McCann et al. 1998). Aquatic food webs may be uncoupled because of species-specific responses by zooplankton (Runge 1988, McQueen et al. 1989, Pace et al. 1998) or fish (Stein et al. 1995). Direct predatory effects of fish may also act simultaneously with nutrient effects to complicate trophic interactions even in relatively simple food webs (Persson 1997, Vanni \& Layne 1997). Furthermore, low efficiency of trophic transfer may allow for weak or nonlinear responses of higher trophic levels to changes at the base of the food web, particularly when changes in phytoplankton are qualitative as well as quantitative (Cushing 1971, Turner 2001). On the other hand, trophic transfer in some estuaries may peak when larvae of common fish species are present (Mallin \& Paerl 1994).

To some extent weak trophic linkages observed in the pelagic food web of the San Francisco Estuary can also be attributed to the open boundaries of the estuary, through which both fish and their food supplies can move, and to extreme temporal variability. In spite of the evidence for strong biological effects at lower trophic levels (e.g. Alpine \& Cloern 1992, Kimmerer et al. 1994), the wider distribution, ontogenetic movement and variable seasonal patterns of most fish species may help to spread the risk (Bennett \& Moyle 1996), and allow them to take advantage of feeding opportunities not represented by a simple model of the estuarine food web. Because estuarine ecosystems are open, models of estuarine populations and food webs may require a certain degree of exogenous forcing to dampen the effects occurring within the food web.
Acknowledgements. Funding for this study was provided by the CALFED Bay-Delta Program and the Interagency Ecological Program for the San Francisco Estuary. I thank Randy Brown for funding, encouragement and helpful discussions, Kathy Hieb, Lee Mecum, Dave Kohlhorst and Diana Watters for providing data, and Alan Jassby, Bill Bennett, Larry Brown, Kathy Hieb and Randy Baxter for comments on various versions of the manuscript.

\section{LITERATURE CITED}

Aleem AA (1972) Effect of river outflow management on marine life. Mar Biol 15:200-208

Alpine AE, Cloern JE (1992) Trophic interactions and direct physical effects control phytoplankton biomass and production in an estuary. Limnol Oceanogr 37:946-955

Ambler JW, Cloern JE, Hutchinson A (1985) Seasonal cycles of zooplankton from San Francisco Bay. Hydrobiologia 129:177-197

Armor C, Herrgesell PL (1985) Distribution and abundance of fishes in the San Francisco Bay Estuary between 1980 and 1982. Hydrobiologia 129:211-227

Arthur JA, Ball MD (1979) Factors influencing the entrapment of suspended material in the San Francisco Bay-Delta Estuary. In: Conomos TJ (ed) San Francisco Bay: the urbanized estuary. Pacific Division, AAAS, San Francisco, p 143-174

Bennett WA, Moyle PB (1996) Where have all the fishes gone? Interactive factors producing fish declines in the Sacramento-San Joaquin Estuary. In: Hollibaugh JT (ed) San Francisco Bay: the ecosystem. AAAS, San Francisco, p 519-542

Boynton WR, Kemp WM, Keefe CW (1982) A comparative analysis of nutrients and other factors influencing estuarine phytoplankton. In: Kennedy VS (ed) Estuarine comparisons. Academic Press, New York, p 69-90

Buchanan PA, Schoellhamer DH (1996) Summary of suspended-solids concentration data, San Francisco Bay, California, water year 1995. US Geological Survey, Sacramento, CA, Open File Report 96-591

Buchanan PA, Schoellhamer DH, Sheipline RC (1995) Summary of suspended-solids concentration data, San Francisco Bay, California, water year 1994. US Geological Survey, Sacramento, CA, Open File Report 95-776

Canuel EA, Cloern JE, Ringelberg DB, Guckert JB, Rau GK (1995) Molecular and isotopic tracers used to examine sources of organic matter and its incorporation into the food webs of San Francisco Bay. Limnol Oceanogr 40:67-81

Christy JH, Morgan SG (1998) Estuarine immigration by crab postlarvae: mechanisms, reliability and adaptive significance. Mar Ecol Prog Ser 174:51-65

Cleveland WS (1993) Visualizing data. Hobart Press, Summit, NJ

Cloern JE (1991) Annual variations in river flow and primary production in the South San Francisco Bay estuary (USA). In: Elliott M, Ducrotoy JP (eds) Estuaries and coasts: spatial and temporal intercomparisons. Olsen and Olsen, Fredensborg, p 91-96

Cloern JE (1999) The relative importance of light and nutrient limitation of phytoplankton growth: a simple index of coastal ecosystem sensitivity to nutrient enrichment. Aquat Ecol 33:3-16

Cloern J, Alpine A, Cole B, Wong R, Arthur J, Ball M (1983) River discharge controls phytoplankton dynamics in the northern San Francisco Bay Estuary. Estuar Coast Shelf Sci 16:415-429 
Cole BE, Cloern JE (1984) Significance of biomass and light availability to phytoplankton productivity in San Francisco Bay. Mar Ecol Prog Ser 17:15-24

Costanza R, D'arge R, De Groot R, Farber S and 9 others (1997) The value of the world's ecosystem services and natural capital. Nature 387:253-260

Cronin TW, Forward RB Jr (1979) Tidal vertical migration: an endogenous rhythm in estuarine crab larvae. Science 205:1020-1022

Cushing DH (1971) Upwelling and the production of fish. Adv Mar Biol 9:255-335

Deegan LA (1990) Effects of estuarine environmental conditions on population dynamics of young-of-the-year gulf menhaden. Mar Ecol Prog Ser 68:195-205

De Jonge VN, Boynton W, D'Elia CF, Elmgren R, Welsh RL (1994) Responses to developments in eutrophication in four different North Atlantic estuarine systems. In: Dyer $\mathrm{KR}$, Orth RJ (eds) Changes in fluxes in estuaries: implications from science to management. Olsen and Olsen, Fredensborg, p 179-196

Drinkwater KF, Frank KT (1994) Effects of river regulation and diversion on marine fish and invertebrates. Aquat Cons Freshw Mar Ecosyst 4:135-151

Drinkwater KF, Myers RA (1987) Testing predictions of marine fish and shellfish landings from environmental variables. Can J Fish Aquat Sci 44:1568-1573

Emmett RL, Stone SL, Hinton SA, Monaco ME (1991) Distribution and abundance of fishes and invertebrates in west coast estuaries, Vol II. Species life history summaries. ELMR Report No. 8, National Oceanic and Atmospheric Administration/National Ocean Survey Strategic Environmental Assessments Division, Rockville, MD

Foe C, Knight A (1985) The effect of phytoplankton and suspended sediment on the growth of Corbicula fluminea (Bivalvia). Hydrobiologia 127(2):105-115

Forbes AT, Benfield MC (1986) Tidal behaviour of post-larval penaeid prawns (Crustacea: Decapoda: Penaeidae) in a southeast African estuary. J Exp Mar Biol Ecol 102:23-34

Gallegos CL, Jordan TE, Correll DL (1992) Event-scale response of phytoplankton to watershed inputs in a subestuary-timing, magnitude, and location of blooms. Limnol Oceanogr 37(4):813-828

Gammelsrød T (1992) Variation in shrimp abundance on the Sofala Bank, Mozambique, and its relation to the Zambezi River runoff. Estuar Coast Shelf Sci 35:91-103

Hager SW, Schemel LE (1992) Sources of nitrogen and phosphorus to northern San-Francisco Bay. Estuaries 15(1): $40-52$

Harden Jones FR, Arnold GP, Greer Walker M, Scholes P (1979) Selective tidal stream transport and the migration of plaice (Pleuronectes platessa L.) in the southern North Sea. J Cons Int Explor Mer 38:331-337

Hatfield SE (1985) Seasonal and interannual variation in distribution and population abundance of the shrimp Crangon franciscorum in San Francisco Bay. Hydrobiologia 129:199-210

Heinle DR, Harris RP, Ustach JF, Flemer DA (1977) Detritus as food for estuarine copepods. Mar Biol 40:341-353

Heubach W, Toth RJ, McCready AM (1963) Food of young-ofthe-year striped bass (Roccus saxatilis) in the SacramentoSan Joaquin River system. Cal Fish Game 49:224-239

Hollibaugh JT, Wong PS (1996) Distribution and activity of bacterioplankton in San Francisco Bay. In: Hollibaugh JT (ed) San Francisco Bay: the ecosystem. AAAS, San Francisco, p 263-288

Holst H, Zimmermann H, Kausch H, Koste W (1998) Temporal and spatial dynamics of planktonic rotifers in the
Elbe estuary during spring. Estuar Coast Shelf Sci 47(3): 261-273

Houde ED, Rutherford ES (1993) Recent trends in estuarine fisheries - predictions of fish production and yield. Estuaries 16(2):161-176

Howarth RW, Swaney DP, Butler TJ, Marino R (2000) Climatic control on eutrophication of the Hudson River estuary. Ecosystems 3(2):210-215

Ingram RG, Legendre L, Simard Y, Lepage S (1985) Phytoplankton response to freshwater runoff: the diversion of Eastmain River, James Bay. Can J Fish Aquat Sci 42: $1216-1221$

Jassby AD (1999) Uncovering mechanisms of interannual variability from short ecological time series. In: Scow KM, Fogg GE, Hinton DE, Johnson ML (eds) Integrated assessment of ecosystem health. Lewis Publishers, Boca Raton, FL, p 285-306

Jassby AD, Cloern JE (2000) Organic matter sources and rehabilitation of the Sacramento-San Joaquin Delta (California, USA). Aquatic Conserv: Mar Freshw Ecosyst 10: $323-352$

Jassby AD, Powell TM (1994) Hydrodynamic influences on interannual chlorophyll variability in an estuary: upper San Francisco Bay-Delta (California, U.S.A.). Estuar Coast Shelf Sci 39:595-618

Jassby AD, Cloern JE, Powell TM (1993) Organic carbon sources and sinks in San Francisco Bay-variability induced by river flow. Mar Ecol Prog Ser 95:39-54

Jassby AD, Kimmerer WJ, Monismith SG, Armor C, Cloern JE, Powell TM, Schubel JR, Vendlinski TJ (1995) Isohaline position as a habitat indicator for estuarine populations. Ecol Appl 5:272-289

Jassby AD, Cloern JE, Cole BE (2002) Annual primary production: patterns and mechanisms of change in a nutrientrich tidal estuary. Limnol Oceanogr 47(3):698-712

Kaartvedt S, Aksnes DL (1992) Does freshwater discharge cause mortality of fjord-living zooplankton. Estuar Coast Shelf Sci 34(3):305-313

Kemp WM, Smith EM, Marvin-DiPasquale M, Boynton WR (1997) Organic carbon balance and net ecosystem metabolism in Chesapeake Bay. Mar Ecol Prog Ser 150: $229-248$

Kimmerer WJ, Orsi JJ (1996) Causes of long-term declines in zooplankton in the San Francisco Bay estuary since 1987. In: Hollibaugh JT (ed) San Francisco Bay: the ecosystem. AAAS, San Francisco, p 403-424

Kimmerer WJ, Gartside E, Orsi JJ (1994) Predation by an introduced clam as the probable cause of substantial declines in zooplankton in San Francisco Bay. Mar Ecol Prog Ser 113:81-93

Kimmerer WJ, Burau JR, Bennett WA (1998) Tidally-oriented vertical migration and position maintenance of zooplankton in a temperate estuary. Limnol Oceanogr 43: 1697-1709

Kimmerer WJ, Cowan JH Jr, Miller LW, Rose KA (2000) Analysis of an estuarine striped bass population: influence of density-dependent mortality between metamorphosis and recruitment. Can J Fish Aquat Sci 57:478-486

Kimmerer WJ, Cowan JH, Miller LW, Rose KA (2001) Analysis of an estuarine striped bass population: effects of environmental conditions during early life. Estuaries 24:556-574

Laprise R, Dodson JJ (1993) Nature of environmental variability experienced by benthic and pelagic animals in the St. Lawrence Estuary, Canada. Mar Ecol Prog Ser 94: 129-139

Laprise R, Dodson JJ (1994) Environmental variability as a factor controlling spatial patterns in distribution and spe- 
cies diversity of zooplankton in the St. Lawrence Estuary. Mar Ecol Prog Ser 107:67-81

Lee CE (1999) Rapid and repeated invasions of fresh water by the copepod Eurytemora affinis. Evolution 53:1423-1434

Lehman PW (1992) Environmental factors associated with long-term changes in chlorophyll concentration in the Sacramento-San-Joaquin Delta and Suisun Bay, California. Estuaries 15(3):335-348

Lehman PW (2000) Phytoplankton biomass, cell diameter, and species composition in the low salinity zone of Northern San Francisco Bay Estuary. Estuaries 23(2):216-230

Livingston RJ (1997) Trophic response of estuarine fishes to long-term changes of river runoff. Bull Mar Sci 60(3): 984-1004

Livingston RJ, Niu XF, Lewis FG, Woodsum GC (1997) Freshwater input to a gulf estuary: long-term control of trophic organization. Ecol Appl 7(1):277-299

Livingston RJ, Lewis FG, Woodsum GC, Niu X and 8 others (2000) Modelling oyster population response to variation in freshwater input. Estuar Coast Shelf Sci 50(5):655-672

Loneragan NR, Bunn SE (1999) River flows and estuarine ecosystems: implications for coastal fisheries from a review and a case study of the Logan River, southeast Queensland. Aust J Ecol 24(4):431-440

Mallin MA, Paerl HW (1994) Planktonic trophic transfer in an estuary: seasonal, diel, and community structure effects. Ecology 75(8):2168-2184

Mallin MA, Paerl HW, Rudek J, Bates PW (1993) Regulation of estuarine primary production by watershed rainfall and river flow. Mar Ecol Prog Ser 93:199-203

Malone TC, Crocker LH, Pike SE, Wendler BW (1988) Influences of river flow on the dynamics of phytoplankton production in a partially stratified estuary. Mar Ecol Prog Ser 48:235-249

McCann K, Hastings A, Huxel GR (1998) Weak trophic interactions and the balance of nature. Nature 365:794-798

McQueen D, Johannes M, Post J, Stewart T, Lean D (1989) Bottom-up and top-down impacts on freshwater pelagic community structure. Ecol Monogr 59:289-309

Meng L, Orsi JJ (1991) Selective predation by larval striped bass on native and introduced copepods. Trans Am Fish Soc 120:187-192

Micheli F (1999) Eutrophication, fisheries, and consumerresource dynamics in marine pelagic ecosystems. Science 285:1396-1398

Miller LW (2000) The tow-net survey abundance index for delta smelt revisited. Interagency Ecological Program for the San Francisco Estuary (Newsletter) 13:37-44

Modlin RF, Orsi JJ (1997) Acanthomysis bowmani, a new species, and $A$. aspera Ii, Mysidacea newly reported from the Sacramento-San Joaquin estuary, California (Crustacea: mysidae). Proc Biol Soc Wash 110:439-446

Monismith SG, Burau JR, Stacey M (1996) Stratification dynamics and gravitational circulation in northern San Francisco Bay. In: Hollibaugh JT (ed) San Francisco Bay: the ecosystem. AAAS, San Francisco, p 123-153

Monismith SG, Kimmerer WJ, Burau JR, Stacey MT (2002) Structure and flow-induced variability of the subtidal salinity field in northern San Francisco Bay. J Phys Oceanogr (in press)

Montagna PA, Kalke RD (1992) The effect of freshwater inflow on meiofaunal and macrofaunal populations in the Guadalupe and Nueces Estuaries, Texas. Estuaries 15(3): 307-326

Moyle PB, Herbold B, Stevens DE, Miller LW (1992) Life history and status of the delta smelt in the Sacramento-San Joaquin Estuary, California. Trans Am Fish Soc 121:67-77
Mueller-Solger A, Jassby AD, Mueller-Navarra D (2002) Nutritional quality of food resources for zooplankton (Daphnia) in a tidal freshwater system (Sacramento-San Joaquin River Delta). Limnol Oceanogr 47:1468-1476

Nichols F, Cloern J, Luoma S, Peterson D (1986) The modification of an estuary. Science 231:567-573

Nichols FH, Thompson JK, Schemel LE (1990) Remarkable invasion of San Francisco Bay (California, USA) by the Asian clam Potamocorbula amurensis. 2. Displacement of a former community. Mar Ecol Prog Ser 66:95-101

Nixon SW, Oviatt CA, Frithsen J, Sullivan B (1986) Nutrients and the productivity of estuarine and coastal marine systems. J Limnol Soc S Afr 12:43-71

Nobriga M (1998) Evidence of food limitation in larval delta smelt. Interagency Ecological Program for the San Francisco Estuary (Newsletter) 11:20-24

Orsi J, Mecum W (1986) Zooplankton distribution and abundance in the Sacramento-San Joaquin Delta in relation to certain environmental factors. Estuaries 9:326-339

Orsi JJ, Mecum WL (1996) Food limitation as the probable cause of a long-term decline in the abundance of Neomysis mercedis the opossum shrimp in the SacramentoSan Joaquin estuary. In: Hollibaugh JT (ed) San Francisco Bay: the ecosystem. AAAS, San Francisco, p 375-401

Orsi JJ, Ohtsuka S (1999) Introduction of the Asian copepods Acartiella sinensis, Tortanus dextrilobatus (Copepoda: Calanoida), and Limnoithona tetraspina (Copepoda: Cyclopoida) to the San Francisco Estuary, California, USA. Plankton Biol Ecol 46:128-131

Pace ML, Cole JJ, Carpenter SR (1998) Trophic cascades and compensation: differential responses of microzooplankton in whole-lake experiments. Ecology 79:138-152

Persson A (1997) Effects of fish predation and excretion on the configuration of aquatic food webs. Oikos 79(1):137-146

Polis GA (1999) Why are parts of the world green? Multiple factors control productivity and the distribution of biomass. Oikos 86(1):3-15

Polis GA, Strong DR (1996) Food web complexity and community dynamics. Am Nat 147:813-846

Postma H (1967) Sediment transport and sedimentation in the estuarine environment. In: Lauff GH (ed) Estuaries. AAAS, Washington, DC, p 158-179

Riley GA (1937) The significance of the Mississippi River drainage for biological conditions in the northern Gulf of Mexico. J Mar Res 1:60-74

Rose KA, Summers JK (1992) Relationships among long-term fisheries abundances, hydrographic variables, and gross pollution indicators in northeastern U.S. estuaries. Fish Oceanogr 1:281-293

Rozas LP, Minello TJ (1997) Estimating densities of small fishes and decapod crustaceans in shallow estuarine habitats: a review of sampling design with focus on gear selection. Estuaries 20:199-213

Runge JA (1988) Should we expect a relationship between primary production and fisheries? The role of copepod dynamic as a filter of trophic variability. Hydrobiologia 167/168:61-71

Siegfried C, Kopache M (1980) Feeding of Neomysis mercedis (Holmes). Biol Bull 159:193-205

Sin Y, Wetzel RL, Anderson IC (1999) Spatial and temporal characteristics of nutrient and phytoplankton dynamics in the York River estuary, Virginia: analyses of long-term data. Estuaries 22:260-275

Sinclair M, Bugden GL, Tang CL, Therriault JC, Yeats PA (1986) Assessment of effects of freshwater runoff variability on fisheries production in coastal waters. In: Skreslet S (ed) The role of freshwater outflow in coastal marine ecosystems. Springer-Verlag, Berlin, p 139-160 
Sitts RM, Knight AW (1979) Predation by the estuarine shrimps Crangon franciscorum Stimpson and Palaemon macrodactylus Rathbun. Biol Bull 156:356-368

Skreslet S (1986) The role of freshwater outflow in coastal marine ecosystems. NATO Advanced Studies Institute Series G. Ecological Science, Vol 7. Springer-Verlag, Berlin

Skreslet S (1997) A conceptual model of the trophodynamical response to river discharge in a large marine ecosystem. J Mar Syst 12(1-4):187-198

Smith SV, Hollibaugh JT (1993) Coastal metabolism and the oceanic organic carbon balance. Rev Geophys 31:75-89

Sommer T, Baxter R, Herbold B (1997) Resilience of splittail in the Sacramento-San Joaquin Estuary. Trans Am Fish Soc 126:961-976

Spratt JD (1981) Status of the Pacific herring, Clupea harengus pallasi, in California to 1980. California Fish Game Fish Bull 171:1-104

Stein RA, DeVries DR, Dettmers JM (1995) Food-web regulation by a planktivore: exploring the generality of the trophic cascade hypothesis. Can J Fish Aquat Sci 52(11): $2518-2526$

Stevens DE (1977) Striped bass (Morone saxatilis) year class strength in relation to river flow in the Sacramento-San Joaquin Estuary, California. Trans Am Fish Soc 106:34-42

Stevens DE, Miller LW (1983) Effects of river flow on abundance of young chinook salmon, American shad, longfin smelt, and delta smelt in the Sacramento-San Joaquin River system. N Am J Fish Manage 3:425-437

Stevens DE, Kohlhorst DW, Miller LW, Kelley DW (1985) The decline of striped bass in the Sacramento-San Joaquin Estuary, California. Trans Am Fish Soc 114:12-30

Stoecker DK, Egloff DA (1987) Predation by Acartia tonsa Dana on plantonic ciliates and rotifers. J Exp Mar Biol Ecol 110:53-68

Strong DR (1992) Are trophic cascades all wet? Differentiation and donor-control in speciose ecosystems. Ecology 73: $747-754$

Sutcliffe WH Jr (1972) Some relations of land drainage, particulate material, and fish catch in two eastern Canadian bays. J Fish Res Board Can 29:357-362

Sutcliffe WH Jr (1973) Correlations between seasonal river

Editorial responsibility: Otto Kinne (Editor),

Oldendorf/Luhe, Germany discharge and local landings of American lobster (Homarus americanus) and Atlantic halibut (Hippoglossus hippoglossus) in the Gulf of St. Lawrence. J Fish Res Board Can 30:856-859

Turner JL, Chadwick HK (1972) Distribution and abundance of young-of-the-year striped bass, Morone saxatilis, in relation to river flow in the Sacramento-San Joaquin estuary. Trans Am Fish Soc 101:442-452

Turner RE (2001) Some effects of eutrophication on pelagic and demersal marine food webs. In: Turner RE, Rabalais NN (eds) Coastal hypoxia: consequences for living resources and ecosystems. Coastal and Estuarine Studies. American Geophysical Union, Washington, DC, p 371-398

Vanni MJ, Layne CD (1997) Nutrient recycling and herbivory as mechanisms in the 'top-down' effect of fish on algae in lakes. Ecology 78:21-40

Venables WN, Ripley BN (1997) Modern applied statistics with S-plus. Springer-Verlag, New York

Vörösmarty CJ, Green P, Salisbury J, Lammers RB (2000) Global water resources: vulnerability from climate change and population growth. Science 289:284-288

Wahle RA (1985) The feeding ecology of Crangon franciscorum and Crangon nigricauda in San Francisco Bay, California. J Crustac Biol 5:311-326

Walters RA, Cheng RT, Conomos TJ (1985) Time scales of circulation and mixing processes of San Francisco Bay waters. Hydrobiologia 129:13-36

Watters DL, Oda KT (2001) Pacific herring, Clupea pallasi, spawning population assessment and fishery management for San Francisco Bay, 1993-94. CA Dept of Fish and Game, Mar Res Admin Rpt 01-1

Werner I, Hollibaugh JT (1993) Potamocorbula amurensisComparison of clearance rates and assimilation efficiencies for phytoplankton and bacterioplankton. Limnol Oceanogr 38(5):949-964

Wilber DH (1992) Associations between freshwater inflows and oyster productivity in Apalachicola Bay, Florida. Estuar Coast Shelf Sci 35:179-190

Wilber DH (1994) The influence of Apalachicola River flows on blue crab, Callinectes sapidus, in north Florida. Fish Bull 92:180-188

Submitted: May 15, 2002; Accepted: August 29, 2002

Proofs received from author(s): October 28, 2002 